\title{
SZERVEZETI BELSŐ KOMMUNIKÁCIÓ
}

\section{ORGANIZATIONAL INTERNAL COMMUNICATION}

\author{
Csüllög Mihály ${ }^{1}$, Matkó Andrea ${ }^{2}$, Váró Kata Anna $^{3}$ \\ ${ }^{I}$ Müszaki menedzser hallgató: Debreceni Egyetem, Müszaki Kar, Müszaki \\ Menedzsment és Vállalkozási Tanszék, 4028 Debrecen Ótemetö utca 2-4, Telefon: \\ +36(52)415-155/77730, mcsullog@lib.unideb.hu \\ ${ }^{2}$ Adjunktus: Debreceni Egyetem, Müszaki Kar, Müszaki Menedzsment és \\ Vállalkozási Tanszék, 4028 Debrecen Ótemetö utca 2-4, Telefon: +36 (52) 415 - \\ 155/77730,andim@eng.unideb.hu
}

${ }^{3}$ Tanársegéd: Debreceni Egyetem, Müszaki Kar, Müszaki Menedzsment és Vállalkozási Tanszék, 4028 Debrecen Ótemetö utca 2-4, Telefon: +36 (52) 415 155/77730,varokata@eng.unideb.hu

\begin{abstract}
Internal communication has a vital role in the everyday operations of organizations. Our aim to describe in details the elements of internal communication, its functions and enlist the key factors aiding or hindering it. We present the questionnaire-based study we carried out concerning the internal communication of a nonprofit organization. The aim of the study is to explore the features of organizational internal communication and to uncover whether the results support our initial hypotheses or not. This publication describe details from this test results.
\end{abstract}

Keywords: internal communication, communication, organization.

\section{Összefoglalás}

A szervezeti belső kommunikációnak kitüntetett szerepe van a szervezetek mindennapi kiegyensúlyozott müködésében. Kutatásunk során a szervezeti belső kommunikáció összetevőit, funkcióit, segítő és gátló tényezőit, fejlesztési lehetőségeit és a szervezetek életében játszott szerepét vizsgáltuk szervezeti belső kommunikációs kérdőív segítségével. Célunk a választott szervezet belső kommunikációs jellemzőinek a feltárása és a felállított hipotéziseink bizonyítása volt. Ebben a tanulmányban az elvégzett vizsgálat részletei kerülnek bemutatásra.

Kulcsszavak: belsö kommunikáció, kommunikáció, szervezet.

\section{Bevezetés}

A XX. század közepétől megnőtt a civil társadalom információs igénye, a közügyekben való részvételi szándéka és az üzleti élettel szembeni érdekérvényesítési törekvése és ez a profit és nonprofit szervezeteket egyaránt arra kényszerítette, hogy a közvetlen befolyásolás helyett a meggyőzésen alapuló kommunikációra, a konszenzust kereső diskurzusra helyezze a hangsúlyt a külső és belső közönségükkel szemben egyaránt. Természetes módon előbb a profitorientált cégek ismerték fel a változás szükségességét, de nyomukban járva a nonprofit területeken is tudatosan kezdték szervezni és tervezni a szervezeti 
kommunikációt, ami elégedettebb belső és külső partnereket eredményezett [5].

\section{A kutatás}

A kutatásunk során egy 120 alkalmazottal müködő nonprofit szervezet dolgozói körében átfogó kérdőíves felmérést végeztünk a szervezet belső kommunikációs jellemzőinek és müködéséi hatékonyságának a feltárására.

A nyereségorientált és nonprofit szervezetek kommunikációja között lényegi különbség nincs [5], így a vizsgálat tárgyát képező szervezet kiválasztásánál a szervezet felépítése és mérete volt a fö irányadó.

A kutatás során alkalmazott kérdőívet Semeginé dr. Tariszka Éva „Szervezeti belső kommunikáció rendszerének korszerü kialakítása"- címü doktori értekezésében használta, így biztosítva volt annak alkalmazhatósága, hitelessége. A mérést 2014 októbere során végeztük és a lezárásáig összesen 64 kitöltött kérdőív került visszaküldésre, tehát a megkérdezettek 53,33 \%-a válaszolt.

Tekintve, hogy többféle csoportosítási szempont is alkalmazva volt a minta kiértékelésénél, így számításba lett véve, hogy 100 fő alatt nincs különösebb értelme a százalékolásnak és 30 fönél pedig az átlag értékek számításának [1], ezért az elemzés során túlnyomórészt átlag és szórásértékekkel lettek reprezentálva a kapott eredmények. Az átlagértékek között a 0,5-es különbség volt szignifikánsnak tekintve.

Jelen rövid tanulmányban részben ismertetve lesz, hogy a belső kommunikáció milyen tényezőket befolyásolhat a szervezet életében a dolgozók elképzelése szerint, valamint a vizsgált szervezetben alkalmazott kommunikációs csatornák használati gyakorisága kerül bemutatásra.

\subsection{Szervezeti belső kommunikáció}

A szervezeten belüli kommunikáció lényegében olyan egy vagy kétirányú közlési folyamat, mely akár élő szóban akár írásos formában információáramlást jelent a vállalati stratégiával, változásokkal és a hétköznapi folyamatokkal kapcsolatosan [4], amely a közös cél érdekében végzett munka tervezését, irányítását, ellenőrzését, értékelését, a múködési feltételek biztosítását, az erőforrások összehangolását teszi lehetővé. Közvetíti az értékeket, a normákat, a szervezeti kultúrát, fontos szerepet játszik a hatalmi struktúrák müködésében, a szervezeti szerepek betöltésében, a munkahelyi légkör alakításában, valamint része van a munkahelyi konfliktusok kialakulásában, kezelésében és megoldásában [2]. "Célja olyan kölcsönösen előnyös kapcsolat létrehozása és fenntartása a szervezet menedzsmentje és alkalmazottjai között, amelytől a szervezet léte és sikeres működése függ [5]."

A szervezeti belső kommunikáció fogalmát teljes mértékben alátámasztja a lefolytatott vizsgálat is. A választ adó alkalmazottak úgy vélekedtek (1. táblázat), hogy a szervezeti belső kommunikáció nagy hatással van a munkahely légkörére $(4,19), \quad$ a vezető-vezetett közötti kapcsolatára $(4,20)$, az egységek egymás közötti viszonyára $(4,19)$, a bizalombizalmatlanság légkörének alakulására $(4,38)$, a konfliktusok generálódására $(4,08)$. Ugyanígy fontosnak tartják a feladatok pontos értelmezésében $(4,28)$, a szervezet müködési hatékonyságában $(4,23)$ és a szervezeti kultúra, a közös értékek közvetítésében $(4,13)$.

A vezetés döntéshozatali mechanizmusára 3,61-os átlagérték lett számítva, ami szignifikánsan eltért a többi átlagértéktöl, de lényegében még jónak mondható. Az alacsonyabb érték oka vélhetően az, hogy a szervezet erösen 
formalizált, és mátrix alapú, magas hierarchiaszintű struktúrával rendelkezik. A legfontosabb döntések így a vizsgált szervezet esetében vezetői értekezleteken születnek, a dolgozók nem vesznek közvetlenül részt a döntéshozatalban, ezért vélhetően úgy gondolják, hogy a szervezeti belső kommunikációnak nincs, vagy nem lehet jelentős hatása a döntések meghozatalában.

1. táblázat. A belsö kommunikáció által befolyásolt tényezők fontossága a válaszadók szerint

\begin{tabular}{|l|c|c|}
\hline & Átlag & Szórás \\
\hline munkatársak közérzetét & 4,19 & 0,774 \\
\hline $\begin{array}{l}\text { vezetö-beosztott közötti } \\
\text { viszonyt }\end{array}$ & 4,20 & 0,717 \\
\hline $\begin{array}{l}\text { szervezeti egységek } \\
\text { egymáshoz való } \\
\text { viszonyát }\end{array}$ & 4,19 & 0,710 \\
\hline $\begin{array}{l}\text { bizalom-bizalmatlanság } \\
\text { légkörének kialakulását }\end{array}$ & 4,38 & 0,807 \\
\hline $\begin{array}{l}\text { szervezeten belüli } \\
\text { konfliktusok } \\
\text { kialakulását }\end{array}$ & 4,08 & 0,783 \\
\hline $\begin{array}{l}\text { vezetés döntéshozatali } \\
\text { mechanizmusát }\end{array}$ & 3,61 & 0,953 \\
\hline $\begin{array}{l}\text { feladatok pontos } \\
\text { értelmezését és } \\
\text { végrehajtását }\end{array}$ & 4,28 & 0,845 \\
\hline $\begin{array}{l}\text { szervezeti müködés } \\
\text { hatékonyságát }\end{array}$ & 4,23 & 0,831 \\
\hline $\begin{array}{l}\text { szervezeti kultúrát és } \\
\text { etikát }\end{array}$ & 4,13 & 0,917 \\
\hline
\end{tabular}

Az egyes válaszlehetőségekre kapott alacsony szóródási értékek jelzik, hogy a dolgozók közel hasonló véleményen vannak, tehát a kapott átlagértékek a szervezet egészére általánosíthatóak.

\subsection{Kommunikációs használata}

csatornák

Az emberek legszívesebben szemtől szembe szeretnek kommunikálni. Ez a forma lehetőséget biztosít az azonnali reflektálásra, válaszadásra, visszajelzésre a kommunikációs partner felé. Ez a kommunikáció kiegészül a nonverbális jelekkel (a személyes kommunikáció során használt jelek $65 \%$-a nem verbális jel, pl. mimika, testtartás, hangsúly és így tovább), ami szavak nélkül segíti, hogy többet tudjunk meg a beszélgető partner pillanatnyi lelki állapotáról, kedvérő és így tovább.

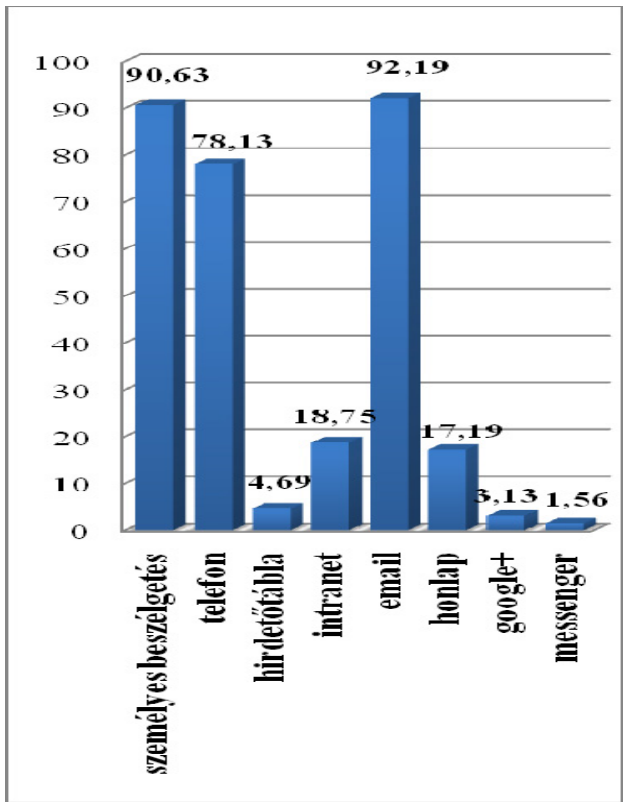

1. ábra. A szervezet alkalmazottai által használt kommunikációs csatornák (\%-os értékek)

A belső kommunikációs csatornák vizsgálatánál a szakirodalmat is alátámasztva a személyes kommunikáció fontossága egyértelmủen igazolódott (1. ábra). A teljes minta értékei alapján kiemelkedik a személyes beszélgetés $(90,63$ $\%$, ami bizonyítja, hogy az emberek 
valóban szemtől szembe szeretnek leginkább egymással információkat megosztani. Az első helyen ennek ellenére az e-mailben (92,19\%) történő üzenetváltás áll. Ezt magyarázza a szervezet széttagoltsága és viszonylag nagy mérete, valamint az, hogy az írásban továbbított információ lehetőséget ad a későbbi ellenőrizhetőségre, valamint hivatkozási alapot is biztosít a felek számára. Ugyanakkor az erősen formalizált szervezetek modernkori legmegfelelőbb kommunikációs csatornája is kétségtelenül az e-mail. A telefon a harmadik legkedveltebb kommunikációs eszközforma volt $(78,13 \%)$. A teljes mintából hárman jelöltek meg egyéb lehetőséget. Két fö a google+-t, és egy a messengert. Rendszerint az ilyen jellegü szoftverek jobb kezelhetőséget és több lehetőséget biztosítanak a felhasználó számára, mint egy egyszerű munkahelyi levelező rendszer, de többnyire nem formalizáltak a szervezetek életében, és emiatt kevesebben is alkalmazzák.

A kommunikációs csatornák használata a vezetők és a vezetettekre is csoportosítva lett és egy fontos megállapítást lehetett tenni. A vezetők 100\%-os mértékben szívesen alkalmazzák a személyes beszélgetés, a telefon és az e-mail adta lehetőségeket, ami mindenképp örvendetes és követendő példa. Ennek oka, hogy a vezető, mint a szervezet menedzsere folyamatosan vezeti, irányítja, koordinálja a szervezet életét, ami megköveteli a kommunikációs csatornák széles körü használatát. Ugyanakkor azt is meg kell jegyezni, hogy ezáltal biztosítva van a dolgozóknak, hogy bármely kommunikációs csatornát is válasszák, nagy valószínüséggel el tudják érni vezetőjüket.

\section{Következtetések}

A modernizált világ, a számítógépek elterjedése abba az irányba mutat, hogy a személyközi kapcsolatok elsorvadhatnak, ezáltal a közvetlen intern kommunikáció is egyre kisebb jelentőséggel fog bírni egy szervezet életében [3]. Az elvégzett kutatás alapján azonban egyértelmüen megállapítható, hogy a dolgozók nagymértékben a személyes kommunikációra alapoznak a munkahelyi információcserében is, ugyanakkor a szervezetek életében kitüntetett szerepet kell betöltenie a belső kommunikációnak, mivel az alkalmazottak is számos a szervezet életét, teljesítményét, müködési hatékonyságát befolyásoló tényező alapvető eszközének tekintik a belső kommunikációt.

\section{Szakirodalmi hivatkozások}

[1] Kabai, I. : A diplomás pályakövető rendszer kutatásainak módszertana. L'Harmattan, 2002. Budapest. ISBN 9789632363554

[2] Karoliny, M., Poór, J. szerk.: Emberi erőforrás menedzsment kézikönyv. Complex, Budapest, 2010. 9789632951089

[3] Karoliny M. [et al.]: Emberi erőforrás menedzsment kézikönyv. KJK-SZÖV, Budapest, 2004. ISBN 9632247248

[4] Nagypál, M.: A munka minőségét rontja a rossz kommunikáció [elektronikus dokumentum] http://www.hrportal.hu/hr/amunka-minoseget-rontja-a-rossz-

kommunikacio-20091014.html (Letöltés idöpontja: 2014.09.10.20:13)

[5] Nyárádi G.: A belső kommunikáció szerepe közintézményekben. In: Múzeumi Közlemények. 2002 1/1 pp. 15-19. ISSN 1589-4959 